\title{
浅谈给水排水工程中的节能减排
}

崔丹

洮南市住房和城乡建设局

DOI:10.32629/btr.v3i2.2890

[摘 要] 目前,水资源紧缺已经成为我国亟需解决的问题之一,水资源供应的不充足性也引发各种连带问题,影响我国经济的发展。为此,有必要 加强对给水排水工程的重视,做好节能减排工作, 以缓解目前存在的水资源短缺问题,改善居民生活品质。

[关键词] 给水排水工程; 节能减排; 生活品质

随着经济的快速发展, 人们的思维意识也在不断加强, 节能理念深入 人心, 并融入到各领域发展中来。水资源节约作为目前人们关注的重点内 容, 做好水资源的科学管控对于人们生产及生活有着积极意义。

\section{1 给排水工程中节能减排的落实意义}

1. 1 降低能耗, 节约成本

在工程开展前, 应结合工程建设要求及市场价格变动情况进行科学的 工程概算, 了解工程建设所需的资金情况, 但由于给排水工程存在特殊性, 所以很难在工程建设前做出科学的成本预算, 这使得工程在建设中经常会 存在能源耗损, 成本浪费等问题, 进而导致给排水建造成本的增加, 在后期 工程运行中, 造成不必要的资源浪费。为此, 有必要在给排水工程中落实节 能减排理念, 以节能减排为目标估算工程大致成本范围, 从而为工程建设 提供可靠依据, 降低不必要的能源损耗。

1. 2加强生态环境保护

能源过度开采及消耗, 不仅会对能源自身储量带来影响, 在使用过程 中还会对生态环境带来严重破坏, 如煤炭开采和应用, 不仅使煤炭总量逐 渐降低, 无法满足生活及生产需求, 煤炭燃烧中产生的有害物质及其金属 元素也会对周边环境带来较大影响, 威胁动植物的生存。故而解决给水排 水施工中能耗过高的问题, 可以有效降低资源的使用量, 减缓生态恶化的 速度, 保护我国的生态环境。

1. 3 促进行业健康发展

传统建筑行业在发展中会造成较大的能源损耗, 不利于我国经济及 环境的稳定发展。所以我国对建筑行业有着诸多限制, 不过在落实节能 减排后, 建筑行业对能源损耗进行了科学控制, 从而推动建筑行业的可 持续前行。

\section{2 给排水工程建设中存在的问题}

2.1给水系统问题

给水系统设置中经常会存在因水压过大而导致的水资源流量过大问
题, 水资源损耗不断加剧, 如此就加重了水资源短缺现象。而出现这一问题 的主要原因是, 相关人员在给水系统设置中, 水压控制意识缺失, 对其重视 力度不足, 进而导致给水系统中水压过高, 系统长时间运行出现水量增大, 水资源渗漏等问题, 从而产生浪费现象。另外, 管理者对存在的渗漏问题解 决不及时, 问题不断增加, 也会影响给水系统的运行效果, 降低用水质量。

2. 2 排水系统问题

排水系统作为给排水工程中较为重要的组成部分, 在规划和运行中会 因为管道材料或外界因素的影响而出现不同程度的渗漏问题, 进而抑制排 水系统的运行, 造成能源的浪费。另外, 由于排水系统具有复杂性, 一旦出 现问题很难在短时间内及时修复, 最终造成大量水资源的流失, 增加耗水 量, 出现供水不足或供水不及时等现象, 阻碍人们的正常生活和工作。

2.3 可再生资源利用率不高

水资源循环利用是增大水资源利用率, 缓解水资源短缺, 促进水资源 可持续发展的重要措施。不过现阶段很多建筑企业都未将水资源循环利用 作为重点研究事项, 在给排水系统设置中, 对污水及外界水资源的处理及 转化效率较低, 如此就降低了水资源的应用效率, 导致水资源短缺问题得 不到有效解决。

\section{3 给水排水工程中节能减排的具体措施}

3. 1 科学控制给排石水压

给排水系统中, 水压会直接影响水源的供应情况, 且随着水压的增大, 水流量也会增多, 这不仅会造成水资源浪费, 还会减短给排水管道的使用 寿命, 不安全因素增多, 阻碍正常生活及生产工作。为此, 在给排水工程规 划中, 应对水压实行科学合理的控制, 并根据供水量要求科学选择管道材 料, 以降低成本, 达到节能减排目的。另外, 给排水工程建设中, 工作人员 也需加大对给排水管道水压控制的重视力度, 对水压变动参数予以实时 监控, 避免超压现象的产生, 必要时可通过减压设备的科学应用, 调解水 压大小, 避免危险的发生。

公路工程沥青路面施工的质量控制非常重要, 涉及很多因素。在实践 中, 要根据工作条件的特点, 加强施工技术要点, 以有效保证路面施工质量, 提高公路工程的施工效率。

\section{[参考文献]}

[1]刘凡清.公路工程励青路面施工现场试验检测技术探讨[J].交通企 业管理,2018,33(05):56-57.

[2]李娜.公路工程沥青路面施工现场试验检测技术研究[J].城市建设 理论研究(电子版),2017,(16):25-26.

[3]张涛.研究公路工程励青路面施工现场试验检测技术 [J]. 现代物业 (中旬刊),2019,(07):213. 
3. 2 加大新型节能技术的推广力度

新型节能技术的推广应用对于实现节能减排有着重要意义。例如目前 市场出现的节能淋浴喷头。使用普通喷头时, 喷头一分钟喷水约在 20 升, 而节能淋雨喷头一分钟只喷水 10 升左右, 节省近一半的水量。以个人洗澡 15 分钟时长来算, 节能淋雨喷头可节省 150 升的水量, 大大降低了水资源损 耗, 且节省下来的水源可被应用到其他区域, 提高人们的生活质量。由此可 知, 推广新型节能技术是非常必要的。下面就对目前较常见的新型节能技 术实行分析阐述。

\subsection{1延时自动关闭与光电控制技术}

该技术可确保水龙头在停止使用的一段时间后实现自动关闭, 减少水 资源浪费。人们日常生活中, 经常会存在忘关水龙头的情况, 尤其是对于家 里有孩子的家庭来说, 这种情况较为常见, 而传统的水龙头在使用过程中, 需要人为的开启和关闭, 一旦忘记, 就会存在水源不断流失的情况, 造成较 为严重的水资源浪费问题, 更有甚者还会影响楼下住户, 给业主带来不必 要的损失。而延时自动关闭水龙头则能够有效解决此类问题, 在固定时间 内自动关闭水龙头, 减少水资源的浪费。结合光电控制技术不仅能够节约 水资源, 还能满足各种人的不同需求, 服务性更强。

3.2.2充气水嘴技术

充气水嘴技术现被广泛应用在厨房及卫生间区域内, 可高效进行水柱 直径的管控, 控制用水量, 达到节能的目的, 再加上该技术应用成本较低, 适用于各类型家庭环境。据相关数据统计, 充气水嘴技术的应用可节约 $10 \%$ 左右的水资源, 且随着楼层高度的增加, 节水效果也会逐渐加强, 对现今的 高层建筑有着较大帮助。充气水嘴技术的应用价值较大且性价比高, 节能 效果好, 值得被广泛推广应用。

3.2.3太阳能技术

太阳能能源具有污染力度小、经济实惠、安全性高等优势, 且储量丰 富, 将其应用在给排水工程中, 可实现节能减排的效果, 降低电能的损耗, 达到节能目标。

3.3 雨水资源的转化及利用

雨水是水资源在自然中循环转化的一种形式。合理应用雨水资源可有
效实现给排水系统节能减排目标。雨水资源的转化及科学利用的范围有很 多, 如景观灌溉、冲则等, 不过其在使用过程中需要对雨水实施适当处理, 以保证雨水质量, 降低污染力度。具体措施为: 先设置雨水沉淀池, 将雨水 导入沉淀池中开展初步净化, 沉淀后的雨水直接排放到蓄水池内, 再利用 水百将其转化到另一个水池中, 转换过程中实施雨水消毒处理, 降低其中 含有的灰尘及有害元素。处理完成后的雨水就可应用到绿化等多领域中。 且也可通过进一步净化处理被用作饮用水。由此可见, 充分利用雨水资源 能有效提高水资源的利用率, 由于大部分地区都存在水资源短缺的情况, 对雨水资源的收集利用, 这能有效缓解水资源不足所造成的压力, 合理利 用水资源。

\section{4 科学选用降耗材料}

降耗材料的科学选用可规避因管材问题导致的渗漏现象。给排水工 程中, 影响管材质量的因素有很多, 如温度、环境等, 而管材是保证给排 水系统正常运转的基础, 只有科学选用管材, 才能改进水质质量, 提高水 源供应效率。所以在设计规划中, 要对管材及其影响因素实行科学把控, 做好质量的严格检查, 并根据管道分布区域的温度变化情况, 选择适合 的管道材料, 以此避免渗漏问题的产生, 增大资源利用率, 达到节能减排 目标。

\section{4 结语}

在给排水工程中落实节能减排理念, 有助于提高水资源利用率, 深化 新型节能技术的应用, 且科学控制水质质量及供应速率, 进而维护人们的 生活生产安全, 促进社会经济的持续发展。

\section{[参考文献]}

[1]忻少华.节能减排技术在市政给排水设计中的应用研究[J].工程技 术研究,2019,4(07):169-170.

[2]董霞.精细化管理在市政给排水工程中应用的几点体会[J].农家参 谋,2019,(05):192.

[3] 俞波. 节能减排在市政给排水设计中的应用 [J]. 科技资 讯,2015,13(35):130-131. 